\title{
A REPORT ON DRIFTING BEHAVIOUR OF ODONATA (AQUATIC INSECTS) IN KYUNJA GAD, A SPRING FED TRIBUTARY OF RIVER MANDAKINI, CHAMOLI GARHWAL, UTTARAKHAND
}

\author{
Pankaj Bahuguna ${ }^{1}$, H K Joshi ${ }^{2}$ and Koshal Kumar ${ }^{3}$ \\ ${ }^{1}$ Bio-diversity Lab, Department of Zoology, A.P.B.Govt.P.G.College Agustyamuni, District Rudraprayag, \\ Uttarakhand-246421, India. \\ ${ }^{2}$ Department of Zoology, Government PG College, Chaubattakhal, Distt. Pauri Garhwal \\ ${ }^{3}$ Department of Zoology, H N B Garhwal University, (A Central University) BGR Campus, Pauri \\ Garhwal-246001, Uttarakhand
}

Corresponding Author Email id: pankajpaurii@gmail.com

Received: 12.10.2019; Revised: 17.11.2019; Accepted: 12.12.2019

(C)Society for Himalayan Action Research and Development

\begin{abstract}
Odonata is an important group of macroinvertebrates which are highly sensitive to environmental changes and pollution. This is the reason why they are mostly studied as change in water quality pattern. The dial study of drifting behavior in such species also indicates towards the feeding behavior of fishes available in that habitat. In the present communication an attempt has been made to view the drifting patterns in a sensitive macro zoobenthic group Odonata in the Kyunja Gad which is a tributary of the snow-fed River Mandakani.
\end{abstract}

Keywords: Odonata, Drifting, Kyunja gad, Mandakini, Rudraprayag

\section{Introduction}

Benthic invertebrates are the important components of the food web in aquatic ecosystems. These insects are an important food of fishes, hence are important component of the aquatic food chain. Odonata larvae depend on the quality of the aquatic habitat, and hence they are sensitive to changes in the environmental settings. Therefore, they have been widely used as bioindicators for environmental health and integrity. In aquatic environments, habitat integrity is an important factor structuring the aquatic communities of insects including Odonata (Souza et al., 2015; Martin and Maynou, 2016). The stream macrozoobenthos have been studied by various workers under specific fields like: ecology and distribution (Zettler and Darius, 2007), substratum relationships (Hynes, 1974; Tuvikene et. al., 2004), Diel migration and drift (Rader and Ward, 1990; Dudgeon, 1990) etc.
Studies on the hill stream macrozoobenthos of Garhwal Himalayan region are made by Dobriyal and Singh (1988), Dobriyal et. al., (1992), Balodi and Koshal, (2015), Koshal et. al. (2017), and Bahuguna and Negi (2018). The drifting macrozoobenthos are studied by various researchers under specific fields like drifting patterns and colonization (Smock, 1996), drift dynamics and Seasonal fluctuations (Dudgeon, 1990,) drifting benthos as indicators of water quality (Kremen, 1992) and drifting of macroinvertebrates in Garhwal Himalaya (Kumar et al., 2006). The present studies was undertaken with the objective to analyse the macrozoobenthos drifting behaviour of Odonata and riparian vegetation in the Kyunja Gad $1^{\text {st }}$ order spring-fed hill stream of the river Mandakani. 


\section{Materials and Methods}

\section{Study Area}

The Kyunja Gad spring-fed hill stream has been selected as the study area. The Kyunja Gad is a tributary of the snow-fed River Mandakani. It is situated in the Latitude $30^{\circ} 25^{\prime} 45^{\prime \prime} \mathrm{N}$ and Longitude $79^{\circ} 08^{\prime} 35^{\prime \prime} \mathrm{E}$ and receives water from numerous springs, underground seepage and surface runoff.

was studied near Senagarsari village at the spot 1 towards the head waters and spot 2 near the Jaykandi (downwards) (Map 1). The first order stream of Kyunja Gad has a stretch of nearly 3.9 Kilometers.

This stream is mainly a Quercus-forest based stream. The stream Kyunja Gad ( $1^{\text {st }}$ order stream)

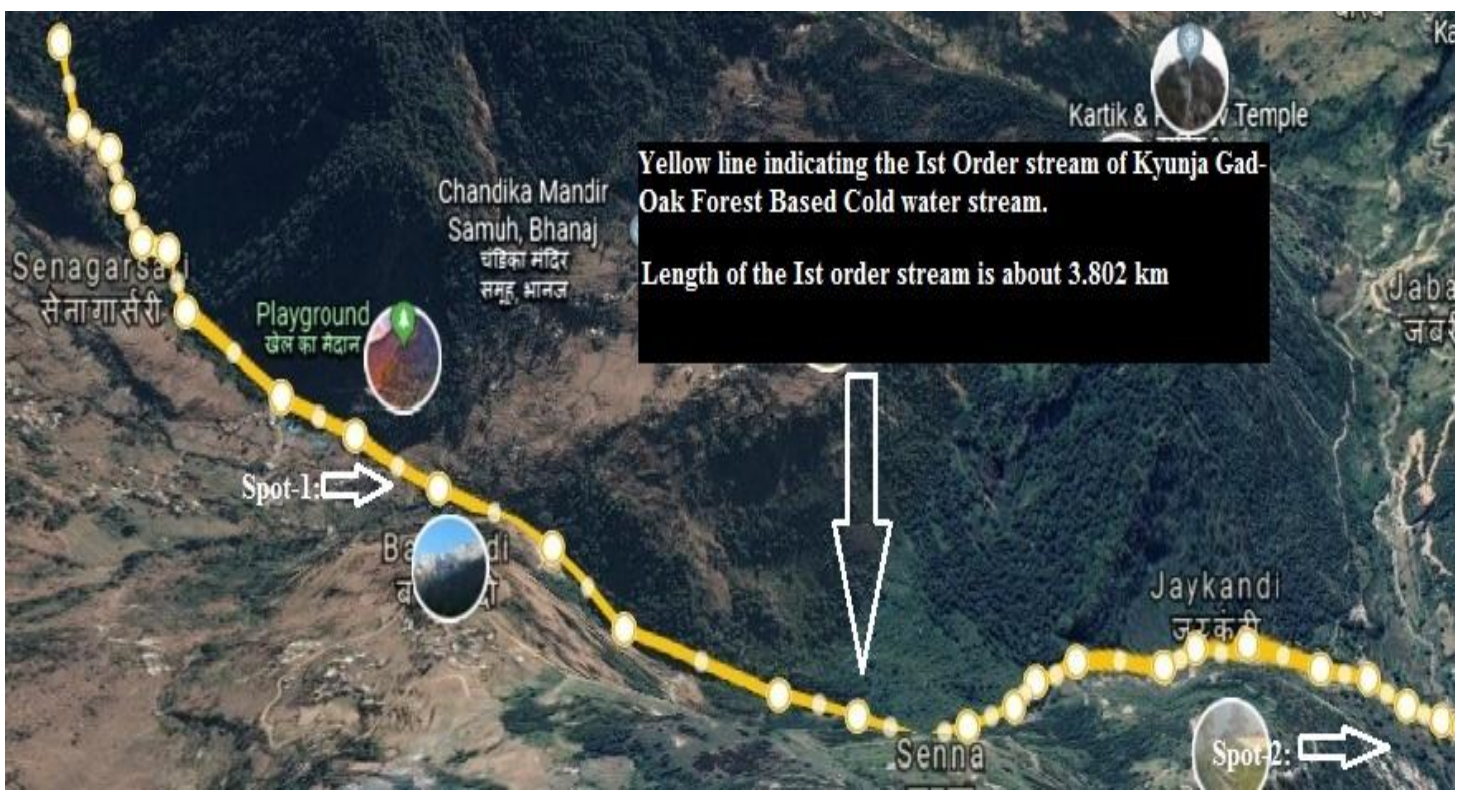

Map 1. Sampling site of $1^{\text {st }}$ order stream Kyunja Gad.

\section{Drifting Sampling}

The Sampling followed the protocol presented by Smock (1996). The drifting Samplers used were essentially the same as those described by FieldDodgson (1985) having an internal diameter of $16.6 \mathrm{~cm}$, a length of $1.7 \mathrm{~m}$ and 220 micron mesh size has been used. As far as possible replicate samples as suggested by Canton and Chadwick (1988) were taken for riffle and runs for increased precision in estimates of total density and species diversity. The drifting benthos were preserved in $70 \%$ ethyl alcohol and brought to the laboratory for enumeration and identification using Ward and Whipple, 1966; Needham and Needham, 1962;
Tomka and Zurwerra, 1985 etc. The identification was done to the lowest possible practical taxon.

\section{Results and Discussion}

Four genera of macro-invertebrates were identified in collections of drift macrozoobenthos from the site on the Kyunja Gad stream. The number of the order Odonata, At the $1^{\text {st }}$ order stream a maximum of 4, 6, 5 individuals $\mathrm{m}^{-3}$ and macrozoobenthos were recorded in drift during December, February and April and minimum of 1 individuals $\mathrm{m}^{-3}$ in November, March and May month in 2017 to 2018 respectively. 
The Argia sp. was single specimen present in December, April, September and was observed to be absent during rest of the months at the $1^{\text {st }}$ order Kyunja Gad stream. The maximum of Zygonyx sp. was observed to be present in the months of February.

The drifting density of Euphaea sp. was very low being 1 individual's $\mathrm{m}^{-3}$ in November, February, April, September and high 3 individual in the month of March. Genus Gompidictus single species was observed in December, April and June in the $1^{\text {st }}$ order stream Kyunja Gad during 2017-
2018 respectively. These lacks of similarity in drift composition no doubt reflect seasonally different sampling times and the variety of stream types so far sampled. Periodicity in benthic invertebrate drift is a well-known phenomenon reported in a wide variety of lotic system throughout the world (Water, 1972). In this study, drifting behaviour was strongly nocturnal in the presence of diurnally feeding fish. At these locations, predator communities were dominated by diurnally active fish and nocturnally active carnivorous Noemacheilus sp.

Table 1: Monthly wise variations in the drifting behaviour of Order -Odonata of the stream Kyunja Gad during the year 2017-18.

\begin{tabular}{|l|l|c|c|c|c|c|c|c|c|c|c|c|c|}
\hline 1 & Odonata & Oct & Nov & Dec & Jan & Feb & Mar & Apr & May & Jun & Jul & Aug & Sep \\
\hline a & Argia & 0 & 0 & 1 & 0 & 0 & 0 & 1 & 0 & 0 & 0 & 0 & 1 \\
\hline b & Zygonyx & 1 & 0 & 0 & 2 & 3 & 1 & 2 & 1 & 1 & 0 & 0 & 1 \\
\hline c & Euphaea & 2 & 1 & 2 & 0 & 1 & 3 & 1 & 0 & 0 & 0 & 0 & 1 \\
\hline d & Gompidictus & 0 & 0 & 1 & 0 & 2 & 0 & 1 & 0 & 1 & 0 & 0 & 0 \\
\hline & Total & 3 & 1 & 4 & 2 & 6 & 1 & 5 & 1 & 2 & 0 & 0 & 3 \\
\hline
\end{tabular}

Flecker (1992) observed that drift periodicity differed among sites that varied in fish faunal composition. Although differences between fish assemblages are in part confounded by elevation, variation in diel periodicity among sites is not easily explained by other changes such as changes in physical factors associated with an altitudinal gradient.

Hieber et. al., (2003) reported that the drifting invertebrates showed no consistent diel periodicity in different alpine streams. In a fishless alpine Kryal stream, however, Robinson et. al., (2002) found distinct diel patterns in which drift density was maximum during day, being associated with the summer afternoon peak in discharge. Discharge during the study period of different alpine sites, however, was relatively constant within a season, showing no significant diel differences and thus, had no influence on diel drift patterns. The nocturnal drift patterns are commonly believed to be an evolutionary response to reduce the risk of predation by visual fish predators (Allan, 1978). Hayes et. al., (2000) opined that reliable quantification of drift is necessary for investigating some aspects of trophic interaction between invertebrates and drift-feeding fish.

\section{Acknowledgement}

First author (P.B.) gratefully acknowledge the financial assistance rendered by Science and Engineering Research Board (SERB) under a major Project No. ECR/2016/001291.

\section{References}

Allan, J. D. (1978).Trout predation and the size composition of stream drift. Limno. Oceanograp. 23: 1231-1237.

Bahuguna, P. and Negi, S. (2018). Distribution Pattern of Benthic Macroinvertebrate Community in the Spring Fed Stream of Garhwal Himalaya, India. J. Mountain Res. Vol. 13: 51-58.

Balodi, V.P, Koshal Kumar, (2015). MacroZoobenthic study in relation to physico- 
Chemical parameters of Khoh River in Uttarakhand. Int. J. Sci. Res. 4 (6): 171-173

Canton, S. P. and Chadwick, J. W. (1988). Variability in benthic invertebrate density estimates from stream samples. J. Freshwater Ecol.. 4: 291- 297.

Dobriyal, A. K. and Singh, H. R. (1988).Ecological basis for icthyofaunal variation in two hillstreams of Garhwal Himalaya. In: Josep, M. (ed.).The first Indian Fisheries Forum Proceeding (pp.313317).Asian Fishery Society, Indian Branch, Mangalore.

Dobriyal, A. K., Bahuguna, A. K., Kumar, N. and Kotnala, C. B. (1992). Ecology and Seasonal diversity of plankton in a spring fed stream Khandagad of Garhwal Himalaya. In. Singh, H. R.(ed.), Adv. Limno: 175-180.

Dudgeon, D (1990). Benthic community structure and the effect of rotenone pesticide on invertebrate drift and standing stocks in two Papua New Guinea streams. Arch. Hydrobiolo. 119: 35- 53.

Field and Dodgson, M. S. (1985). A simple and efficient drift sampler. N. Z. J. Mar. Freshwater. Res. 19: 167- 172.

Flecker, A. S. (1992). Fish predation and the evolution of invertebrate drift periodicity: evidence. Ecol 73(2):438-448.

Hayes, J.W., Stark, J.D., and Shearer, K.A (2000). Development and test of a whole-lifetime foraging and bioenergetics growth model for drift -feeding brown trout. T. Am. Fish. Soc. 192: 315-332.

Hieber, M., Robinson, C. T. and Vehlinger, U. (2003). Seasonal and diel patterns of invertabrate drift in different alpine stream types. Freshwater Biol. 48: 1078-1092.

Hynes, H. B. N. (1974). Further studies on the distribution of stream animals within the substratum.-Linnol. Oceanogr. 19: 92-99.

Koshal Kumar, Jitendra Singh Rana, Anita Rawat Rana, Kotnala, C.B., (2017). Checklist of benthic macroinvertebrate communities of Stream Rawasan in Garhwal region (Central Himalaya), Uttarakhand (India). J. Mountain Res. (12): 91-95
Kremen, C. (1992). Assessing the indicator properties of species assemblages for natural areas monitoring. Ecol. Appl., 2:203-217

Kumar, N. Sangwan, S. and Gupta A. (2006). Macroinvertebrate drift in a Garhwal Himalayan Hillstream. J Mountain Res., 1:2129.

Martín, R. and Maynou X. (2016). Dragonflies (Insecta: Odonata) as indicators of habitat quality in Mediterranean streams and rivers in the province of Barcelona (Catalonia, Iberian Peninsula). Int. J. Odonatol, 19: 107-124.

Naiman, R.J. and Sedell, J.R., (1979). Characterization of particulate organic matter transported by some Cascade Mountain streams. J. Fis. Board Canada, 36(1): 17-31.

Needham, 1. G, and Needham, P. R. (1962). A guide to the study of freshwater biology. San Francisco Holden Day Inc. 108 PP.

Rader, R. B. and Ward, J. V. (1990). Diel migration and microhabitat distribution of a benthic stream assemblage. Can. J. Fish. Aquat. Sci.. 47 (4): 711-718.

Remsburg, A.J., Olson, A.C. and Samways M. J. (2008). Shade alone reduces adult dragonfly (Odonata: Libellulidae) abundance. J. Insect Behav. 21, 460-468.

Robinson, C. T. Tockner, K. and Burgherr, P. (2002). Seasonal patterns in macroinvertabrate drift and seston transport in streams of an alpine glacial flood plain. Freshwater Biol., 47: 985-994.

Sagir, M. and Dobriyal, A. K. (2017). Diversity of riparian vegetation in Western Nayar valley on selected experimental spots. J. Mountain Res.12: 115-118.

Sagir, M. and Dobriyal, A.K., (2018). Influence of riparian vegetation on detritus standing stock of western Nayar valley Uttarakhand. Int. Res. Anal. Rev. 5 (04): 1051-1064.

Smock, L. A. (1996). Macroinvertebrate movements: Drift, colonization and emergence. In Hauer, $F$. $R$. and G. A. Lamberti(eds.), Methods in stream ecology, Academic Press, New York.

Souza, A., Fogaça, F., Cunico, A. and Higuti J. (2015). Does the habitat structure control the 
distribution and diversity of the Odonatofauna? Braz. J. Biol., 75(3), 598-606.

Tomka, I. and Zurwerra, A. (1985). Key to the genera of the Heptageniidae (Ephemroptera) of the Holarctic, Oriental and Ethiopian region. Em. Ber. Luzern. 14: 113- 126.

Tuvikene, L. Kisand,A., Tonno, I. and Noges, P. (2004). Chemistry of lake water and bottom sediments. In Lake Vortsjarv (Haberman, J., Pihu, E. and Raukas, A.,eds), pp. 89-102. Estonian Ecyclopaedia Publishers, Tallinn.

Ward, H. B and Whipple, G.V. (1966). Freshwater Biology (ed. W.T. Edmondson). J. Wiley and sons. Inc. New York 1203 pp.

Waters, T. F. (1972). The drift of stream insects. A. Rev. En. 17: 253-272.

Zettler, M. L. and Darius . D. (2007). Long- term macrozoobenthas changes in a shallow baxel lagoon: Comparion of a recent biodiversity inventory with historical data. Limnologica.37:170-185. 